\title{
UNDERSTANDING THE INTER-LINKAGE OF INNOVATIONS - THE FINNISH FLAT GLASS AND VALUE ADDED INDUSTRIES
}

\author{
Olavi UUSITALO \\ Tampere University of Technology, Tampere, Finland \\ E-mail: olavi.uusitalo@tut.fi
}

doi:10.13165/IE-14-8-2-07

\begin{abstract}
Technological innovation plays an important role in the process of long-run growth. There are many studies on the country and aggregate level innovativeness, patents, etc. This paper, on the contrary, focuses on two individual innovations, float glass and safety glass manufacturing technology, introduced in the late 1950s and the inter-linkage of these innovations in Finland. The flat glass and safety glass industries were both international and very tightly interlinked. We illustrated the evolution of the flat glass industry and its valueadded industries. The government policy towards foreign companies is tracked, as well. The study period is from 1960 to 1985 .
\end{abstract}

JEL classification: L16, M16, O33, O38.

Keywords: inter-linkage of innovation, networks, government policy, flat glass

\section{Introduction}

Technological innovation plays an important role in the process of long-run growth (Furman and Porter, 2002). There are a lot of studies on country level innovativeness, patents, etc. (Furman and Porter, 2002) The focus of this paper is on two individual innovations, float glass, and Lamino safety glass technologies, and the understanding of the inter-linkage between two innovations from a perspective of a small economy, that of Finland. Float glass was introduced in 1959 in the UK while Lamino safety glass technology in the late 1950s in Finland. We track the change caused by two innovations in the Finnish flat glass industry and 
value-added industries, the safety glass and multi glass unit (MGU) industries. We give a special focus on the role and abilities of policy-makers. The study period is 35 years from 1960-1985.

The aim of the paper is to get an understanding of the inter-linkage of two innovations, float glass and safety glass machinery. The Finnish industries were compact, had international contacts and were relatively well documented. From the innovations perspective, the linkages with neighboring countries are thus crucial, and they should also be facilitated by policy-makers (Boschma, 2004). A Central-European multinational company (MNC), Pilkington has been identified as the key change agent shaping the evolution of the industries in the 1970s and the 1980s, Uusitalo (1995, 1997a\&b and 2009), Uusitalo and Mikkola (2010) and Mikkola and Uusitalo (2010). We use evolutionary economics (Boschma and Sotarauta, 2007) in analyzing the policy aspects. The inter-linkage of innovation is conceptualized within the fit of innovations within an acquisition. The fit is analyzed by the core competence (Prahalad and Hamel, 1990) offered by of a small entrepreneurial firm (SEF), the position of SEF in the acquiring foreign MNC's factory network (Ferdows, 1997) and the characteristics (Burns and Stalker, 1961) of the acquiring foreign MNC.

We have the following research questions:

- What is the role of government in the evolution of industries?

- How to recognize the inter-linkage of innovations?

The research methodology for studying long-term impacts of innovations is a longitudinal, historical case study (Yin, 1984). Since there are inter-linkages between industries and between countries and regions, a rich contextual case study works.

The rest of the paper is developed in three sections. In the beginning, a brief literature review is done on the connectedness of firms and industries, national system of innovation (NSI), evolutionary economics, an international factory network within an MNC and core competence. Then, a discussion on methodology follows. The empirical part includes first, a brief history of the Finnish national system of innovation and second, the evolution of the Finnish flat glass industry and its value added such as safety glass and MGU industries. Finally, the role and way of the Government and the understanding of inter-linkage of innovations are discussed. This section includes theoretical and managerial implications plus suggestions for further research.

\section{Literature}

Håkansson and Snehota (1989) emphasize the interdependence between the companies and the networks: "no business is an island". According to them in strategic management business is primarily seen as a production function focusing to operate (internal resources) based on the criterion of efficiency. Instead, companies should be seen as transaction functions and they should shift focus "away from the control of resources towards the integration of resources and away from the management of acting towards the management of reacting". 
There exists a rich literature on the national system of innovation (NSI), which also includes the government innovations policy (Lundvall, 2010b, Freeman, 1982/2004). Dosi, Pavitt and Soete (1990) related the innovation to the foreign trade while Freeman and Soete (1988) analyzed employment issues related to technical innovation. Pavitt's (1984) taxonomy helped to understand how different sectors interact and fulfill different functions in the whole innovation process. Etzkowitz and Leydesdorff (2000) introduced Triple Helix model to combine universities, companies, and the government. Porter (1990) has argued that competitive advantage is created and sustained through a localized process.

Evolutionary economists claim that nations and regions sooner or later will face a decline in their economies (Maskell and Malmberg, 1999). The long-term competitiveness of a country and a region rests on its capabilities to upgrade the economic base by creating variety, to phase out variety-destroying processes due to exits and imitation (Boschma, 2004). According to evolutionary theory, the emergence of new basic variety (such as new sectors) is very hard to predict. New paths cannot be planned and foreseen. They emerge quite spontaneously and unexpectedly (Boschma and Lambooy, 1999). Thus, policy-makers have to cope with uncertainty when promoting economic renewal and restructuring in their countries and regions (Moreau, 2004). The history of countries and regions will have an impact on available options and probable outcomes of policies that focus on developing new growth paths (Boschma, 2005). Thus, growth trajectories will not come out of the blue, but will reveal patterns of historical continuity (Boschma and Sotarauta, 2007).

Evolutionary economy theory sees that in policy-making one should be more sensitive to identifying the potential for emergent developments and routes to the future, and to finding the best possible policy-making ways to each situation, location and time in question, recognizing the emerging processes and not creating totally new invented policies from scratch. In fact, this suggests that policy-makers ought to know much better what is going in their own region to build on existing strengths and capabilities in regions to stimulate innovation (Lambooy and Boschma, 2001). Another key aim of evolutionary innovation policy is to connect agents with the purpose of facilitating knowledge transfer. The evolutionary policy should provide access to information. Access to variety is important for innovations because it triggers new ideas, but it provides complementary assets needed for the development of innovations, as well. The policy should focus on facilitating connections with non-local agents. The higher the number of connections with the outside world, the more information, and the more variety is brought into the region through extra-territorial linkages (Boschma, 2004). Thus, the access to variety and information, internal and external to the respective region, is crucial in development.

Ferdows (1997) classifies strategic roles of the factories within a MNC based on the extent of technical activities and primary strategic reasons (access to low cost production, use of local technological resources and proximity to market) for the site. Lead factories serve as partners of headquarters in building strategic capabilities in the manufacturing function. These factories usually are the sole or major producer of certain products or components for companies' global markets (Ferdows, 1997). Core competencies can be seen of as consisting 
of bodies of technological expertise (both products and processes) and the organizational capacity to deploy that expertise effectively. They reinforced through continued continuous use and were therefore to some extent firm-specific, non-transferable and difficult to imitate (Prahalad \& Hamel, 1990).

The technical capacity transfer involves the transfer of scientific knowledge and the capacity to develop new technology. Technical skills are often tacit, context-dependent and embedded in individual and teams. The efficient transfer is, therefore, difficult. It often requires the creation of an atmosphere or culture to allow communication and to learn to take place. Mutual trust, appreciation of each other's competence and acceptance of common goals is needed, as well (Håkanson, 1995). Datta's (1991) found that differences in top management styles have a negative impact on performance even in low levels of managerial integration. According to Jemison and Sitkin (1986) the strategic fit, while important, is not a sufficient condition for superior acquisition performance. The synergies must be realized through effective post-acquisition integration. Symbiosis is characterized by a high degree of interdependence because substantial technical capability transfers must take place (Haspeslagh and Jemison, 1991). Burns and Stalker (1961) identified organic and mechanistic organization structure. The first one should be more suitable for an innovative organization.

\section{Research methodology}

Our case study may be described as longitudinal, historical and contextual. We use multiple case study method and multiple data sources (such as industry and company histories, business, trade and academic journals plus interviews with the industry experts) in this study (Yin, 1984). The single case can represent a significant contribution to knowledge and theory building. A longitudinal case study can usually better capture firm dynamics over time (Pettigrew, 1990; Siggelkow, 2007). The most important is the depth of the analysis, both in terms of the number of factors studied and sources of information used (Yin, 1984). A single case analysis is the best way to get a holistic picture and understanding of the research problem. Patton (1990, p. 95) has argued that "qualitative inquiry is highly appropriate for studying processes because depicting a process requires detailed description."

Porter (1980) points out that in an industry analysis there are important benefits in getting an overview of the industry first, and only then focusing on the specifics. First, I had to get an overview of the industry before I focused the specifics. The teaching case (Uusitalo, 1993) was a tool to achieve an overview. According to him, experience has shown that a broad understanding can help the researcher to spot important items of data when studying sources and organize data more effectively as they are collected. Porter (1981) also stresses the value of in-depth industry histories in understanding industry environments and identifying firms' strategic interactions on a longitudinal basis.

To improve the validity of our "analysis" we used the triangulation methods described by Jick (1979) and Pettigrew (1990) to construct case studies from a variety of information sources: personal interviews with 1993-2012 (business managers in Pilkington for instance Sir 
Antony Pilkington, Chairman of Pilkington, Jonas Borup, MD of Lahti Glass Works, Erkki Artama, Lamino Pilkington Automotive; Prof. Barker, the author of three histories, and Prof. Pearson, a former Pilkington employee, Bror Wahlroos, Secretary General 1969-1992, Ministry of Trade and Industry), company and industry histories written by professional historians (Barker, 1977 and 1994; Hast, 1991; Daviet, 1989; PPG, 1967 and 1983; Spoerer et al., 1987), industry and technology studies or books (Berg, 1984; Doyle, 1979; Persson, 1969; Pilkington, 1963 and 1976; Takahashi and Ichinose, 1980), business periodicals (Mushakoji, 1986; Salmans, 1980; Wierzynski, 1968), books written by businessmen, company correspondence, academic studies (Frederiksen, 1974; Skeddle, 1977) and journals, news clippings from the mass media, statistics and trade journals (The Glass Industry and Ceramic Industry Magazine; all from the area 1950-1984).

Archival records (i.e. industry statistics, production volumes, import, and export) were also used (Uusitalo, 1997a\&b). The statistics can be regarded as reliable source. The documentation of the data and archival records are filed in chronological order. The analysis of the data is important in the case of explanatory and causal studies. Internal validity can be enhanced by doing pattern recognition (Mintzberg, 1979) or seeing the evidence through multiple lenses (Eisenhardt, 1989). Table 1 provides a list of different perspectives.

Table 1. Viewing the research phenomenon from different perspectives

$\quad \begin{aligned} & \text { Perspective } \\ & \text { Technology }\end{aligned}$
Technology transfer
Industry
Economy large
small
Global
Global
large (MNC)
small
Vertical integration

\section{Focus of analysis}

Plate, sheet and float glass manufacturing processes

Safety glass manufacturing technologies

Wholly-owned subsidiary, licensing or joint venture

The plate glass, sheet glass and safety glass industries

The UK, France, Germany

Scandinavian countries (including Finland)

Licensing of float glass

Licensing of float glass

Pilkington, St. Gobain, PPG, Asahi Glass

Sheet glass and safety glass manufacturers

The safety glass and MGU -industries 


\section{Flat glass industry, innovations and related industries}

This chapter provides an empirical illustration first of the Finnish national innovation system (NSI) or policy and then the flat glass technologies and value-added products. Two innovations, float glass and safety glass machinery, are also discussed briefly. This chapter also includes the description the evolution of the flat glass, safety glass and MGU industries.

\section{The Finnish national system of innovation (NSI)}

There is always an interaction between industrial, economic and social structure and public policy orientation that impact on the structure of the innovation system and policies (Lemola, 2002). The basic foundations of technology and science policies or NSI were partly built in the 1960s, but mainly in the 1970s and 1980s. The aim of them was to lift the technological level of Finnish industries and to reduce the dependence on raw material-driven production and exports. The Finnish National Fund for Research and Development (Sitra), was established in 1967 to support industrial R\&D. Moreover, the Ministry of Trade and Industry began in 1968 to support the research and product development of firms, and it also received an additional appropriation for goal-oriented technical research. At the end of the 1970s, Finland's research and development (R\&D) expenditure relative to gross domestic product (GDP) was one of the lowest in the industrialized countries. A key matter in the early 1980s was to make technology policy more target-orientated and systematic. (Hermans et al., 2005) To fulfill these tasks, Tekes (The National Technology Agency) was founded in 1983. In Oulu, for example, the first technology center of the Nordic Countries was established in 1984 (Lemola, 2002).

During the 1990s, there was a clear shift of emphasis in innovation and industrial policies. While in the 1980 s policy thinking was more or less based on the idea of picking the winner's, policies adopted in the 1990s can be labeled as enabling policies. The emphasis moved towards indirect measures in influencing firm behavior, avoiding direct interventions in the product market, promoting competition, and providing a stable macroeconomic environment. (Hermans et al., 2005) In 1990, the concept of an NSI as a framework for science and technology policies was introduced to illustrate the systemic nature of innovation. The innovation process and policies should be looked from a broad perspective ranging from education and science to innovative activities of firms and commercialization of technological innovations (Miettinen, 2002). Finland can be regarded as one of the few countries that have developed a consistent approach towards a network and cluster facilitating innovation policy (Schienstock and Hämäläinen 2001).

\section{Flat glass technologies and processed product with their raw materials}

As late as the mid-1970s two different sub-industries existed in the flat glass industry (see Figure 1). The plate glass industry was much more concentrated, and companies were 
larger than those in the sheet glass (window glass is used as a synonym) sub-industry. Every plate glass manufacturer also made sheet glass, which did not require such expensive machinery. The peripheral markets, such as Scandinavia, were fragmented, and producers operated in national markets. Float glass was introduced in the plate glass and the sheet glass industries in 1959 and in 1968-70, respectively. In the late 1960s and the mid-1970s, float glass overtook the plate glass and the sheet glass processes, respectively (see Figure 2 for the case in the US). The flat glass industry became a single industry.

Safety glass (both laminated and tempered) and MGUs are two types of processed flat glass products (see Figure 3). Less expensive tempered safety glass is used in the side and rear windows of cars and carriages while the laminated glass is for security and windshields. Safety glass was invented in the 1920s. Single glazing gives unsatisfactory insulation against cold and sound in windows. Prefabricated insulating glass units are preferred to two or three individual panes of glass in a window. The MGU units were developed in the US and Germany in the 1930s.

Figure 1: The Division of flat glass (industries)

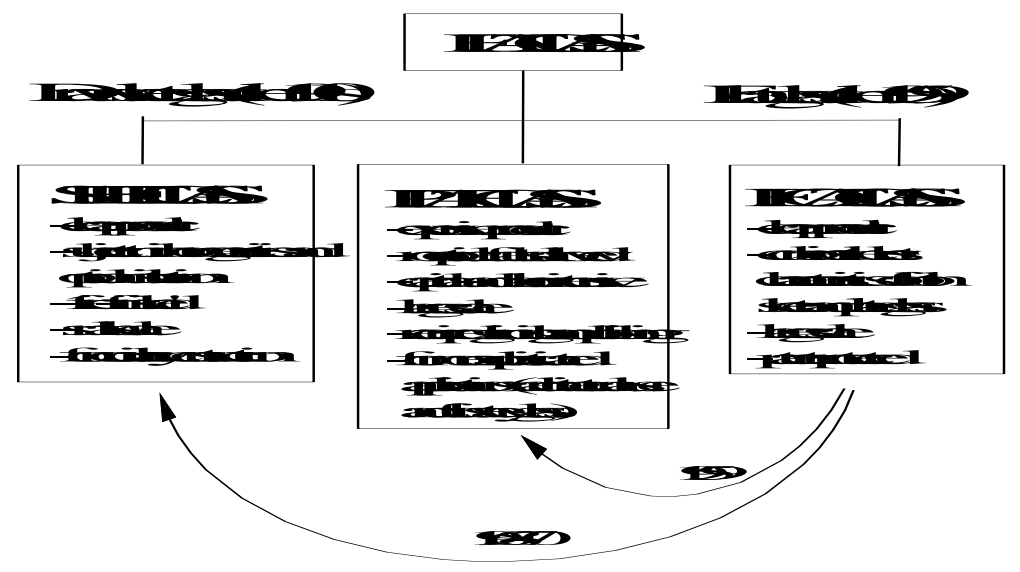

Source: Uusitalo (1995) 
Figure 2: The US flat glass production in 1959 to 1977

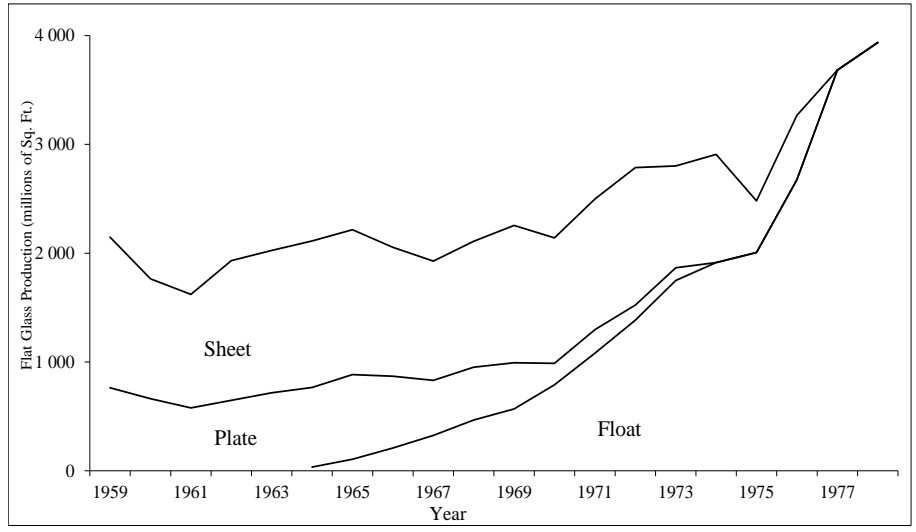

Source: Uusitalo (2014)

Figure 3: Processed value added products and their raw material

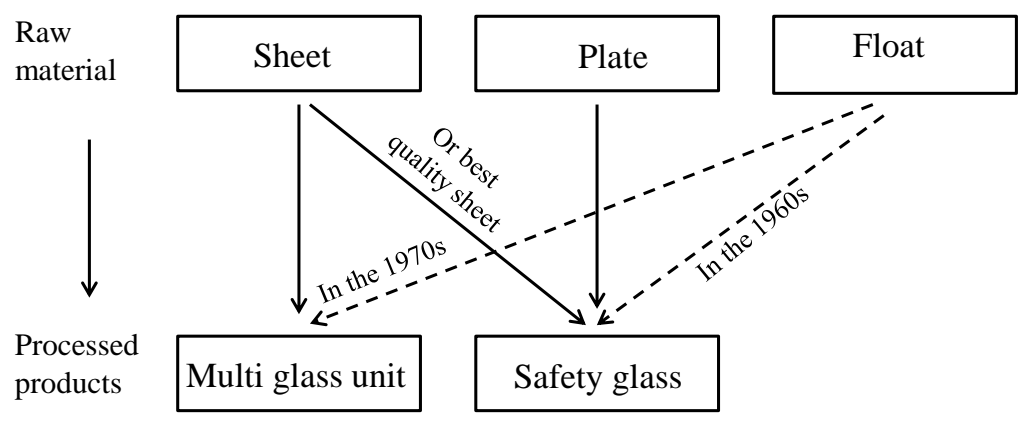

Source: Uusitalo (1995)

\section{Flat glass industry}

This chapter illustrates the flat glass industry in three areas, Central Europe, Scandinavia and Finland plus the float glass innovation. 


\section{Central Europe}

Two large local companies, Pilkington (founded in 1826) from the UK and St. Gobain (founded in 1665) from France have produced both in sheet and plate glass throughout the twentieth century. In the mid-1920s both of them began to produce plate glass with a continuous casting, grinding and polishing methods. At the same time, they entered the safety glass business. St. gobain had been interested in the Scandinavian market since the mid-1940s when it acquired 30\% from the Swedish flat glass manufacturer, Emmaboda. Pilkington looked in the late 1960s at the Scandinavian flat glass and the safety glass market when it bought the first Swedish windshield manufacturer, Sunex to acquire a marketing channel for its float glass sales.

\section{The float glass innovation}

Pilkington introduced float glass in 1959 (Barker, 1994). In 1962, it built its second and third float glass lines. In 1967, the company closed its last plate glass line. The company decided to license the technology. In 1962, the first license was old to the U.S. based PPG. In the late 1960s and in the early 1970s, St. Gobain invested in nine float glass lines. By 1970, Pilkington and St., Gobain introduced float glass in the sheet glass industry. They also became interested in the Scandinavian sheet glass market. Concentration in the flat glass industry took place. Since 1970, the German flat glass industry was owned by foreign companies. BSN (Boussois-Souchon-Neuvesel) acquired the German Flachglass and the Belgian plate and sheet glass manufacturer, Glaverbel, in 1970 and in 1972, respectively. In 1979 BSN withdrew from the flat glass industry by selling its French operation to PPG from the U.S., its German operations (Flachglas) to Pilkington, and its Belgian operations (Glaverbel) to Asahi Glass from Japan.

\section{Scandinavia}

By 1960 in Scandinavia (including Finland) there were seven independent sheet glass manufacturers (Korsör in Denmark, Lahti Glass Works (LGW), Riihimäki and Valke in Finland, Drammen in Norway and Emmaboda plus Gränges/Oxelösund in Sweden). In the 1960s all companies, except Valke, manufactured MGUs, as well. Plate glass was never manufactured in Scandinavia. In the 1950s, all Scandinavian manufacturers used the European Fourcault technology. In 1959 (added capacity 1968) and in 1966 Emmaboda and Drammen started PPG machines, respectively. In 1969 in Denmark Scanglas (a merger between Öxelösund and Korsör) and in Finland LGW started new PPG plants, as well. In 1974, LGW added two more PPG machines. In 1974, Riihimäki licensed technology from the Japanese Asahi Glass (Takahashi and Ichinose, 1980) to modernize its Fourcault machines. At the same time the Scandinavian safety glass and MGU industries grew. 
In 1973, local sheet glass producers tried to form, together with either St. Gobain or Pilkington, a joint float glass manufacturing company, Scandifloat. However, the project failed since Pilkington wanted the majority ownership in the project, and Emmaboda was sold to St. Gobain in 1974. In 1974, Pilkington started massive imports from Scandinavia to achieve a market share and distribution outlets for its float glass plant (started in 1976) in Sweden. The struggle for capacity in the market created a price war in Scandinavia in the mid-1970s. This was called a Great Glass War. By 1978 St. Gobain had bought the Swedish, Norwegian and Danish flat glass producers. In 1978, Pilkington acquired a 50 per cent share in LGW. The market was controlled totally by two large Central-European MNCs. In less than 20 years, seven independent local flat glass manufacturers had disappeared. By 1984, sheet glass production was terminated in Scandinavia.

\section{Finland}

In 1967 three companies, LGW 58\%, Riihimäki 22\% and Valke $20 \%$, produced the domestic supply of flat glass (45,000 tons). Five strong central wholesalers took care of the domestic sales. Around $7.5 \%$ of the demand was imported. Import duties and the lack of size standardization restricted imports. Finnglas was an export organization created by the local flat glass manufacturers. Flat glass export accounted $13 \%$ of production. In the 1950 s and 1960 s the European as well as the Finnish sheet glass manufacturers had successful exports to the U.S. Overall, the flat glass industry was characterized by slow growth, dependence on the building sector and cost increases in labor and raw materials (Sitra, 1970). In 1969, LGW and Riihimäki formed a cartel by sharing the domestic market; the former made MGUs and the latter safety glass for the construction industry. With its new plant, LGW was able to meet all demand in Finland. In the early 1970s, the export to the U.S. shrank because float glass had started to compete with sheet glass, as well. In 1972, Valke left the industry. In 1974, LGW bought a local safety glass manufacturer, Autolasi. At the same time, LGW had troubles to mount two additional machines. A one-year production stop created a shortage of flat glass.

Meanwhile, a Finnish wholesaler owned by Finnish glaziers, Lasitukku, imported huge amounts of Pilkington's float glass. It also controlled most of the distribution system. As we saw, the Scandifloat project was terminated. Emmaboda canceled the export agreement with LGW. The huge overcapacity in the market presaged a price war. Large investments, warehouses full of glass and rapidly changed market conditions put LGW in a critical financial condition. It had to two alternatives; either quitting or cooperating with one of the two large Central-European MNCs. In 1975, Riihimäki temporarily discontinued its sheet glass production. One year earlier the company had acquired a license from Asahi to modernize its existing obsolescent machines.

In 1976, the Finnish Government decided neither to make LGW as a state-owned company nor prevent companies importing flat glass. At the same year, LGW promised to Pilkington to lower its production and to continue its sheet glass production only for three years. Then LGW would manufacture only MGUs. The Government let the price of flat glass 
rise $25 \%$. Next year a committee evaluating the Finnish glass industry suggested that only LGW would continue its sheet glass production. In 1978 Pilkington, the Finnish Government and the financing bank of LGW arranged the ownership (Pilkington 50\%, the bank 25\%, two Finnish private companies $10 \%$ and a government $5 \%$ ) of LGW. Bror Wahlroos, Secretary General, Ministry of Trade and Industry, lead the two-year long negotiations. The furnace was repaired and sheet glass production continued until 1984 when a float glass plant investment decision of $€ 50$ million was made. The float glass line (70,000 tons/year) was inaugurated in 1987. The ownership of LGW was as follows: Pilkington (44\%), the Finnish Government (33\%) and Finnish private companies (23\%). Wahlroos represented the Finnish Government again. Appendix 1 summarizes the events in the flat glass, safety glass, and MGU industries.

\section{The safety glass machinery innovation and the Finnish safety glass industry}

Lamino was found in 1949. In 1957, the first laminated curved windscreens for busses were manufactured. In the early 1960s, the U.S. plastic supplier Monsanto became interested in the safety glass manufacturing process of Lamino and offered to export them to the developing countries. However, the first safety glass machinery line was delivered to the U.K. in 1963. After that, Lamino sold numerous manufacturing lines to Europe and South America. It also licensed manufacturing technology to two companies in Sweden. In the early-1970s, Lamino concentrated on safety glass manufacturing. In 1975, the owner family sold Lamino, the largest manufacture in Scandinavia, sold to Pilkington with the approval of the Government. Bror Wahlroos arranged the sale of Lamino to Pilkington. The raw material supply was the main reasons for the sale for Lamino and the guarantee of float glass sales for Pilkington. LGW became also interested in buying Lamino. Under Pilkington, Lamino grew rapidly. In 1979, Lamino acquired Nordlamex, another Finnish safety glass producer. In the late 1980s, Lamino had 50 per cent share in the European windscreen market for buses, and it also delivered windscreens as genuine spare parts to the Japanese Toyota and Mitsubishi cars in Europe. In 1992, Lamino's turnover was $€ 75$ million, it had 900 employees and exported 87 per cent of its production to 35 countries. The Finnish safety glass industry has grown remarkably within thirty years (see Appendix 2).

\section{Finnish MGU industry}

The MGU-product market expanded in the early 1970s. Lahti had played a leading role, or it had even a monopoly in this industry since the company had introduced Polarpane products on the Finnish market in the mid-1960s. The Polarpane technology was sublicensed from a Swedish flat glass manufacturer in 1965. Through advertisements and promotion campaigns, Lahti created demand for MGU products. However, many glaziers, Lahti's customers, and other companies also became interested in MGU products. After float glass was introduced in Finland in 1963 the power of local flat glass manufacturers was diluted, and new comers entered the industry (see Table 2). LGW was competing with several local firms. 
Table 2: Largest MGU-producers in 1975-76

Capacity (thousand $\mathrm{m} 2$ )

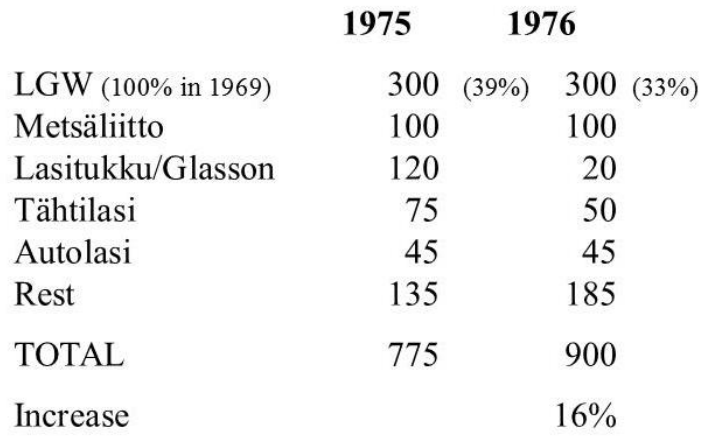

Source: Talouselämä 26/1975

\section{Discussions and conclusions}

As we saw the Finnish national system of innovation was basically developed not until the 1990s, which means that the models / taxonomies created by Lundvall (2010b), Freeman, (1982/2004), Dosi, Pavitt and Soete (1990), Pavitt (1984) and Freeman and Soete (1988) do not explain the involvement of the policy-maker in the Finnish flat glass industry. Etzkowitz and Leydesdorff's (2000) Triple Helix model combining universities, companies, and the government is not valid either since such kind of co-operation did not exist in Finland in the 1970s and 1980s.

Bror Wahlroos, Secretary General, Ministry of Trade and Industry, was a welleducated person, had the industrial background and was an eager reader. He must have been also diplomatic since he had to get along with 25 ministers during his career in the Ministry of Trade and Industry.

In the 1950s, two pertinent innovations took place. In Finland, Lamino started working on the flat glass to manufacture windscreens. Lamino's consistent quality of windscreens provided real customer value for the local bus manufacturer. In the 1950s three windscreen manufacturers, Muotolasi, Autolasi and Nordlamex, and in 1970 one, Tamglass, emerged as spin-offs from the company. Lamino's manufacturing technology was well known word-wide. The company and the safety glass industry grew rapidly in the 1960s and the 1970s.

In the meantime, Pilkington invented float glass process which accelerated the globalization of the flat glass industry. Large flat glass producers became interested in safety 
glass firms as distribution outlets. Pilkington had already in the 1930s acquired safety glass manufacturers in the Common Wealth countries to guarantee the sales of plate glass (Barker, 1977). In 1968 and 1973 Pilkington acquired two Swedish firms, which used Lamino's manufacturing technology. In the early 1970s, Lamino imported cheap float glass from a U.S. based newcomer, Guardian Industries. In 1971, Lamino managed to enter the UK safety glass market during the six weeks strike in Pilkington. Triplex, the daughter company of Pilkington, had after the strike difficulties in gaining back the domestic safety glass market. With these incidents and connections, Pilkington and Lamino had noticed each other. Lamino and Nordlamex were sold to Pilkington in 1975 and 1979, respectively. Under Pilkington, these firms grew rapidly (see Appendix 2).

After imported float glass had become available in Finland, the MGU industry was no more LGW's monopoly. Float glass broke the existing rigid value chain. The era of the mid1970s was called the Great Glass War throughout Scandinavia (see Appendix 1).

As was mentioned Wahlroos was involved in the arrangement of the Finnish flat glass and safety glass industries. Already in 1970 just after joining the Ministry of Trade and Industry he was involved at the end state of Sitra's (1970) study of the Finnish flat glass industry. By the way, Sitra's study did not include the value added industries, the safety glass, and MGU industries. Neither did it mention Lasitukku, which started to import Pilkinton's float glass in the early 1970s. Very soon, Wahlroos created a vision that the flat glass and safety glass industries were closely inter-linked. Moreover, the Finnish markets would be linked to the globalizing European market, as well. For instance, since 1970 the German flat glass manufacturers were owned by foreign companies although the strong German industry endowment.

In 1975 while arranging the sale of Lamino to Pilkington Wahlroos has linked several matters: 1) Pilkington had licensed very strictly (not to destroy the industry) float glass (see Wierzynski, 1969); 2) float glass was globalizing the industry; 3) Germany had no domestic flat glass producers; 4) float glass was taking over sheet glass (see Figure 2 in the U.S.); 5) sheet glass manufacturing had no future (allow Pilkington buy Lamino although the local LGW was interested and during the Lamino negotiation keep in mind a solution for the Finnish flat glass); 6) the MGU industry was no longer LGW's monopoly; 7) there was no need to put import duties on float glass; 8) Lamino was a competent manufacturer but it was not possible for it to survive alone; 9) Pilkington could provide raw material for Lamino; 10) Moreover, Chairman Lord Pilkington (1969) illustrated the ethical code of the Pilkington company by saying:

"There are two schools of thought. One (the second) believes that business is only shortsighted and selfish, in the late 19th-century image; this is widely believed by governments everywhere, but specially in developing countries. The other (the first) is that business is adult and farsighted, realizing that self-interest should be enlightened, that cooperation and good conduct pay, that we are 20th and 21 st century, not 19 th. I believe the first school of thought, from long experience, but we in international business have to prove it to be true - and do so in the face of growing nationalism." 
The impact of Wahlroos inter-linked view of two innovations, float glass and safety glass manufacturing technology, is conceptualized in Figure 4. A successful continuation of a small entrepreneurial firm (SEF) has three prerequisites. Lamino's unique manufacturing, sale and sourcing capabilities (experienced by Pilkington while acquiring Swedish companies, during its strike in the UK and selling float glass in competition with Guardian Industries) could provide core competence for Pilkington (Prahalad \& Hamel, 1990). Before the acquisition, Lamino was able to evaluate its position in Pilkington's factory network (Ferdows, 1997). Lamino could earn a lead factory role in Pilkington in Ferdows' (1997) typology. Third, the buying company should have at least organic organisation structure (Burns and Stalker, 1961) to be able to allow and guarantee a subtle integration process and symbiotic life after the acquisition.

According to Haspeslagh \& Jemison (1991), Granstrand \& Sjölander (1990) and Håkanson (1995), etc. the integration of a technology based company is a risky process. Lamino was sold to Pilkington in 1975. The integration process was subtle. The technical director, the son of the founder of Lamino, was nominated to MD. The R\&D unit remained the same, and no controller came from Pilkington. The integration process of Lamino seemed to resemble the symbiosis proposed by Haspeslagh \& Jemison (1991). Pilkington's organisation structure seemed to be organic. The acquisition was successful.

Figure 4: The success concept for a small entrepreneurial firm (SEF)

Requirements for a SEF:

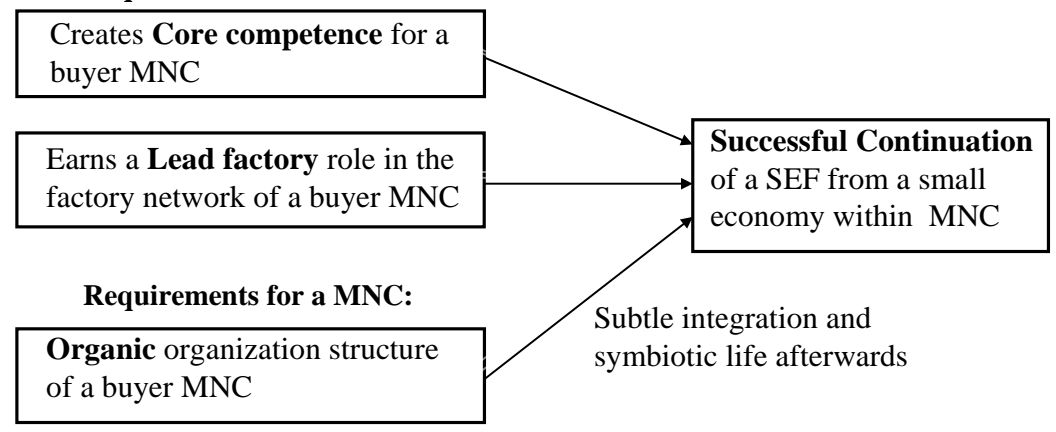

In 1977, he was the chairman of the committee to evaluate what is the further arrangement in the Finnish flat glass industry. After LGW was in March 1976 close to bankruptcy Wahlroos conducted a two years long negotiation between Pilkington, Finnish companies, and the Government in order to continue the sheet glass manufacturing in Finland. In the mid-1980s, he was again conducting the negotiations between Pilkington, the Finnish companies, and the Government. 
Wahlroos had a fresh vision of the inter-linkages between the flat glass (and float glass innovation) and safety glass industries (and Lamino's safety glass manufacturing technology) and their belonging to a larger international context. He also recognized the emerging safety glass industry as a new developing sector as mentioned by Lambooy and Boschma (2001). He enhanced the existing connections of Finnish firms to foreign firms such as Pilkington and also facilitated new connections as emphasized by Boschma (2004). It seems that Wahlroos personally was executing evolutionary policy (Boschma and Sotarauta, 2007) himself.

This paper enlarges Ferdows' (1997) typology to be used in the analysis of acquisitions of SEFs. An SEF can benchmark its position within the factory network of a potential buyer MNC.

According to Porter, (1990) competitive advantage of nations is created and sustained through a localized process. Porter's (1990) diamond for success includes 1) factors of production, such as skilled labor or infrastructure, necessary to compete in a given industry, 2) the nature of home-market demand for the industry's products, 3) the presences or absence of related and supporting industries and 4) firm strategy, structure, and rivalry. It seems that in the case of the Finnish safety glass industry and glass tempering solutions the Porter's (1990) does not explain the success of them. As we saw individual entrepreneurs have started the industry without any local skilled labor or infrastructure, without home-market demand (no for instance car manufacturing), without related industries (the flat glass industry was busy with the construction industry) and competition.

In this kind of study, a longitudinal, contextual case study with rich data is utmost important to give a comprehensive view of the evolution of the industry. Studies executed purely on quantitative methods may have traps in understanding all events in the evolution of industries. One example of comparison between quantitative and qualitative research methods is provided by Uusitalo (2014).

Further research includes two ideas. Since Porter's (1990) diamond did not explain the emergence and growth of the Finnish safety glass industry and glass tempering solutions since the 1960s, it would be interesting to study what were the enabling factors. Second, recently several Finnish firms have been sold to foreign large MNCs (Vacon to the Danish Danfoss, VTI Technologies to the Japanese Murata Electronics) such as Lamino to Pilkington in 1975. Lamino's acquisition was successful as we can see its development in 1975 to 1992 (Appendix 2). Lamino got resources for production investments and responsibility to take care certain markets. It would be interesting to validate within a large sample the conceptualization (Figure 4) of the sale of the small entrepreneurial firm to a foreign MNC.

\section{References}

1. Barker, T. C. (1977). The Glassmakers. Pilkington: the Rise of an International Company 1826-1976, London: Weidenfeld and Nicholson. 
2. Barker, T. C (1994). An Age of Glass. Pilkington. The Illustrated History, London: Boxtree.

3. Berg, B. (1984). Det Stora Glaskriget (The Glass War), Huddinge: Glasmästeribranschens Service.

4. Boschma, R. A. (2004). Competitiveness of regions from an evolutionary perspective, Regional Studies, 38(9), 1001-1014.

5. Boschma, R. A. (2005). Rethinking regional innovation policy. The making and breaking of regional history, in G. Fuchs and Shapira, P. (eds.), Rethinking regional innovation and change. Path dependency or regional breakthrough, New York: Springer, 249-271.

6. Boschma, R. A. and Lambooy, J. G. (1999). Evolutionary economics and economic geography, Journal of Evolutionary Economics, 9, 411-429.

7. Boschma, R. A. and Sotarauta, M. (2007). Economic policy from an evolutionary perspective: the case of Finland, International Journal of Entrepreneurship and Innovation Management, 7 (2-5), 156-173.

8. Burns, T. \& Stalker, G. M. (1961). The Management of Innovation, London: Tavistock.

9. Datta, D. K. (1991). Organizational fit and acquisition performance: Effects of Post-Acquisition Integration, Strategic Management Journal, 12: 281-297.

10. Daviet, J-P. (1989). Une multinational a la Française. Paris: Histoire de SaintGobain 1665-1989, Fayard.

11. Dosi, G., Pavitt, K. and Soete, L. (1990). The Economics of Technical Change and International Trade. Hemel Hempstead: Harvester Wheatsheaf.

12. Eisenhardt, K. M. (1989). Building theories from case study research, Academy of Management Review, 14, 532-550.

13. Etzkowitz, H. and Leydesdorff, L. (2000). The dynamics of innovation: from National Systems and "Mode 2" to a Triple Helix of university-industry-government relations, Research Policy, 29(2): 109-123

14. Ferdows, K. (1997) Making the Most of Foreign Factories, Harvard Business Review, March - April, pp. 73-88.

15. Frederiksen, P. C. (1974). Prospects of Competition from Abroad in Major Manufacturing Oligopolies: Case Studies of Flat Glass, Primary Aluminum, Typewriters, and Wheel Tractors, unpublished Ph.D. dissertation, Washington State University.

16. Freeman, C. (1982). The Economics of industrial innovation. London: Pinter Publishers.

17. Freeman, C. (2004). Technological infrastructure and international competitiveness, Industrial and Corporate Change, 13(3): 540-52.

18. Freeman, C. and Soete, L. (Eds.) (1988). Technical change and full employment. Oxford: Basil Blackwell.

19. Furman, J. L., Porter, M. E. and Stern, S. (2002). The determinants of national innovative capacity, Research Policy, 31, 899-933. 
20. Granstrand, O. and Sjölander, S. (1990). The Acquisition of Technology and Small Firms by Large Firms, Journal of Economic Behavior and Organisation, 13, 367-386.

21. Haspeslagh, P. C \& Jemison, D. B (1991) Managing Acquisitions: Creating Value Through Corporate Renewal, Free Press, New York.

22. Hast, A. (ed.) (1991). International Directory of Company Histories, Volume III, London: St James Press.

23. Hermans, R., Kulvik, M. and Ylä-Anttila, P. (2005) International mega-trends and growth prospects of the Finnish biotechnology industry: Recent economic research and policy implications. Journal Of Commercial Biotechnology, 11(2), 134-145.

24. Håkansson, H. and Snehota, I. (1989). No Business is an Island: The Network Concept of Business Strategy, Scandinavian Journal of Management, 4 (3): 187-200.

25. Håkansson, L (1995) Learning through Acquisitions, International Studies of Management \& Organizations, 25(1-2): 121-157.

26. Jemison, D. B. and Sitkin, S.B. (1986). Corporate Acquisitions: A Process Perspective, Academy of Management Review, 11(1): 145-163.

27. Jick, T. D. (1979). Mixing Qualitative and Quantitative Methods: Triangulation in Action, Administrative Science Quarterly, 24, 602-611.

28. Lambooy, J. G. and Boschma, R. A. (2001). Evolutionary economics and regional policy, The Annals of Regional Science 35, 113-131.

29. Lemola, T. (2002). Convergence of national science and technology policies: the case of Finland. Research Policy. 31, 1481-1490.

30. Lundvall, B.-A. (2010a). Chapter 15 Post script: Innovation system research where it came from and where it might go, in Lundvall, B.-A. (Ed.), National systems of innovation: Toward a theory of innovation and interactive learning (317-349). London: Pinter.

31. Lundvall, B.-Å. (2010b). (Ed.) National systems of innovation: Toward a theory of innovation and interactive learning. London: Pinter.

32. Maskell, P. and Malmberg, A. (1999). The competitiveness of firms and regions. 'Ubiquitification' and the importance of localized learning, European Urban and Regional Studies, 6(1), 9-25.

33. Miettinen, R. (2002). National Innovation System: Scientific Concept or Political Rhetoric. Edita. Helsinki.

34. Mikkola, T. and Uusitalo, O. (2010). Making strategic decisions in the changing networks - observations from the Scandinavian flat glass industry, the 26th IMP Conference, 2nd-4th of September 2010, Budapest, Hungary.

35. Mintzberg H. (1979). An Emerging Strategy of "Direct" Research, Administrative Science Quarterly, 24, 683-589.

36. Moreau, F. (2004). The role of the state in evolutionary economics, Cambridge Journal of Economics, 28, 847-874.

37. Mushakoji, K. (1986). The Process of Internationalization at Asahi Glass, International Management, March, 73-74 and 79-80. 
38. Pavitt, K. (1984). Sectoral Patterns of Technical Change: Towards a Taxonomy and a Theory. Research Policy, 13, 343-373.

39. Patton, Q. M. (1990). Qualitative Evaluation and Research Methods, Newbury Park: Sage Publications.

40. Persson, R. (1969). Flat Glass Technology, London: Butterworths.

41. Pilkington, A. (1963). The Development of Float Glass, The Glass Industry, February, 80-81 and 100-2.

42. Pilkington, A. (1976). Flat Glass - Evolution and Revolution Over 60 Years, Glass Technology, 17, 182-193.

43. Pilkington, H. (Lord, Chairman of Pilkington) (1969) The Role of International Corporations in World Commerce, The Glass Industry, August, 371-373.

44. Porter, M. (1980). Competitive Strategy, New York: Free Press.

45. Porter, M. (1981). Strategic Interaction: Some Lessons from Industry Histories for Theory and Anti-trust Policy. In Steven C. Salop (ed.) Strategy, Predation and Anti-trust Analysis, Washington, D.C.: Federal Trade Commission, 449-506.

46. Porter, M. (1990). The Competitive Advantage of Nations. London: Macmillan Press Ltd.

47. PPG (1967) Romance of Glass, Public Relations Department, Pittsburgh.

48. PPG (1983) A Century of Achievement, PPG Products Magazine, Volume 91, 2, pp. 1-33.

49. Prahalad, K. K \& Hamel, G (1990), The Core Competence of the Corporation, Harvard Business Review, May-June, pp. 9-91.

50. Salmans, S. (1980). Pilkington's Progressive Shift, Management Today, September, 66-73.

51. Schienstock, G. and Hämäläinen, T. (2001). Transformation of the Finnish innovation system: A network approach, Sitra Reports series 7, Helsinki: Sitra.

52. Siggelkow, N. (2007). Persuasion with case studies. Academy of Management Journal, 50(1), 20-24.

53. Sitra (1970). Research on the International Competitiveness of the Finnish Glass Industry (in Finnish), Helsinki: The Finnish Innovation Fund.

54. Skeddle, R.W. (1977). Empirical Perspective on Major Capital Decisions, unpublished Ph.D. Dissertation, Case Western Reserve University.

55. Spoerer, M., Busi, A. and Krewinkel, H. W. (1987). 500 Jahre Flachglas, 14871987 Von der Waldhütte zum Konzern (in German) Schorndorf: Karl Hofmann Verlag.

56. Takahashi, S. and Ichinose, M. (1980). New Vertical Draw Process for Sheet Glass, The Glass Industry, April, 24, 29-30 and 32.

57. Uusitalo, O. (1993) Pilkington Goes North: Competition in Scandinavian Flat Glass Market (HSE, an unpublished teaching case).

58. Uusitalo, O. (1995). A Revolutionary Dominant Design - The Float Glass Innovation in the Flat Glass Industry. Dissertation A:108. Helsinki: Helsinki School of Economics. 
59. Uusitalo, O. (1997a). Development of the Flat Glass Industry in Scandinavia 1910-1990: the Impact of Technological Change. Scandinavian Economic History Review, (3): 276-295.

60. Uusitalo, O. (1997b). Globalization of an Industry - a Network Perspective. The Case of the Scandinavian Flat Glass Industry, IMP Paper, Lyon 1997.

61. Uusitalo, O. (2009). Lasinteon tärkeät päätökset. Etelä-Suomen Sanomat, Vierailija, 22.3.2009, p. 13.

62. Uusitalo, O. (2014). Float Glass on the Flat Glass Industry. SpringerBriefs in Applied Sciences, Heidelberg: Springer.

63. Uusitalo, O. and Mikkola, T. (2010) Revisiting the case of float glass Understanding the industrial revolution through the design envelope, European Journal of Innovation Management, 13(1): 24-45.

64. Wierzynski, G. H. (1968), The Eccentric Lords of Float, Fortune, July, 90-2, 1214.

65. Yin, R. K. (1984) Case Study Research, Design and Methods, Sage Publications.

\section{About the Author:}

Olavi UUSITALO - Professor of Marketing, $\mathrm{Ph}$. D. Institute of Industrial Management, Tampere University of Technology. 
Appendix 1. Impact of two innovations on the industries.

Four spin offs

Safety glass

Windscreens (safety glass)

- machines to make windscreens for buses

The sale of Lamino to Pilkington (1975)

- the Gov. Bror Wahlroos, Sec. General MTI

Licensing / dominant design / globalizing
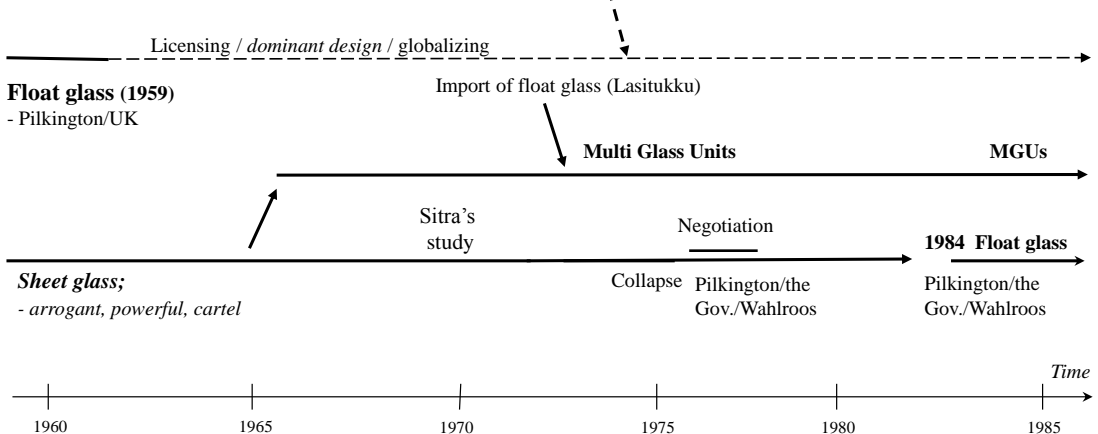

Appendix 2. Laminated safety glass export from Finland (for cars and other vehicles)

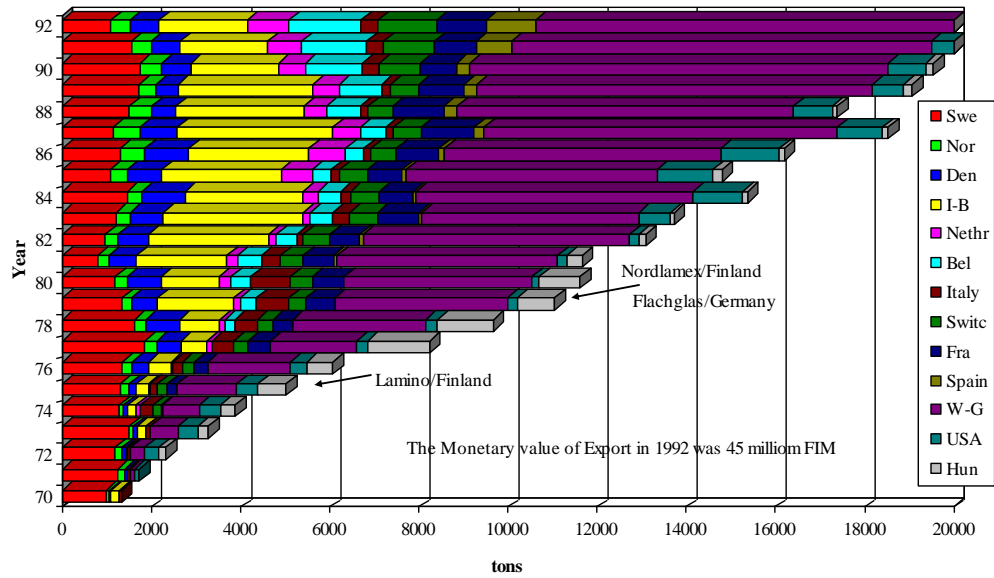

Arrows indicate time when companies were acquired by Pilkington 